\title{
Three New Cultivars of Cornus kousa: Empire, Pam's Mountain Bouquet, and Red Steeple
}

\author{
Phillip A. Wadl ${ }^{1}$ and Mark T. Windham \\ Department of Entomology and Plant Pathology, University of Tennessee, \\ 2505 E.J. Chapman Drive, 370 Plant Biotechnology Building, Knoxville, TN \\ 37996
}

\section{Richard Evans}

Department of Forestry, Wildlife, and Fisheries, University of Tennessee, 274 Ellington Plant Science Building, Knoxville, TN 37996

\section{Robert N. Trigiano \\ Department of Entomology and Plant Pathology, University of Tennessee, 2505 E.J. Chapman Drive, 370 Plant Biotechnology Building, Knoxville, TN 37996}

Additional index words. Cornaceae, columnar form, fused bracts, kousa dogwood, ornamental Cornus kousa 'Empire', 'Pam's Mountain Bouquet', 'Red Steeple'

The genus Cornus contains 58 species of trees, shrubs, and herbs that are mostly distributed throughout the northern hemisphere (Xiang et al., 2006). Flowering dogwood ( $C$. florida), kousa dogwood (C. kousa), and their interspecific hybrids are considered the most popular and economically significant members of the genus in the nursery and landscape industries. These deciduous trees are valued for their spring display of pink, red, or white bracts, brilliant-red fall foliage, and exfoliating bark. Retail and wholesale sales of dogwood in the United States account for over $\$ 30$ million dollars annually with $73.1 \%$ of these sales coming from eight states [Maryland, Minnesota, New Jersey, North Carolina, Ohio, Oregon, Pennsylvania, and Tennessee (U.S. Dept. of Agriculture-National Agricultural Statistics Service, 2010)]. Sales in Tenneessee account for $21.9 \%$ of total sales of deciduous flowering trees, making it an important crop for the state's economy. Additionally, six counties in Tennessee produce substantial amounts of 1-year-old liners that are sold to out-of-state nurseries for finishing and resale. In nursery production, a liner refers to a small tree that is transplanted and allowed to become a larger tree for sale by wholesale or retail outlets. These liners ultimately supply $\approx 80 \%$ of the country's dogwoods (Simmons, 2002). Large-bracted dogwoods are widely grown throughout midtemperate regions of eastern North America, both in the wild and as coveted ornamental trees in urban and suburban landscapes. Across this range, flowering dogwoods have been severely affected by dogwood anthracnose [Discula

Received for publication 21 May 2014. Accepted for publication 23 June 2014.

${ }^{1}$ To whom reprints should be addressed; e-mail pwadl@utk.edu. destructiva (Redlin, 1991)] and powdery mildew [Erysiphe pulchra (Li et al., 2009)].

Because of the importance of dogwoods to the U.S. agricultural economy, an improvement program was initiated over 20 years ago at the University of Tennessee to develop disease-resistant cultivars of dogwoods. These efforts have resulted in the release of the first flowering dogwood cultivar (Appalachian Spring) with resistance to dogwood anthracnose (Windham et al., 1998) and three powdery mildew resistant cultivars: Jean's Appalachian Snow, Karen's Appalachian Blush, and Kay's Appalachian Mist (Windham et al., 2003).

Cornus kousa is more tolerant to anthracnose and powdery mildew than $C$. florida (Holmes and Hibben, 1989; Ranney et al., 1995). Hybrids between these two species are generally more vigorous than typical plants of either parent species and have field resistance or tolerance to dogwood anthracnose and powdery mildew (Ranney et al., 1995). There are over 100 named cultivars of $C$. kousa and many cultivars are the result of either selection of open-pollinated seedlings or spontaneous sports rather than systematic breeding (Cappiello and Shadow, 2005).

The objective of this project was to evaluate $\approx 400$ seedlings of $C$. kousa for disease resistance and horticultural traits such as color, degree of overlap, size of bracts, tree form, and bark and leaf characteristics. From these, three genotypes were selected for development and release.

\section{Origin}

The origin of the C. kousa seedlings and methodology for disease screening is


Fig. 1. Cornus kousa 'Empire' (A) original tree at 20 years old, (B) brilliant white bracts, (C) exfoliated bark. 
Table 1. Cornus kousa 'Pam's Mountain Bouquet' fused bract characteristics for 2008-11.

\begin{tabular}{lrccr}
\hline Yr & Not fused & One side fused & Two sides fused & All sides fused \\
\hline $2008(\mathrm{n}=50)$ & $7(14 \%)$ & $3(6 \%)$ & $12(24 \%)$ & $28(56 \%)$ \\
$2009(\mathrm{n}=50)$ & $10(20 \%)$ & $1(2 \%)$ & $4(8 \%)$ & $35(70 \%)$ \\
$2011(\mathrm{n}=50)$ & $9(18 \%)$ & $5(10 \%)$ & $9(18 \%)$ & $27(54 \%)$ \\
Mean & $(17 \%)$ & $(6 \%)$ & $(17 \%)$ & $(60 \%)$ \\
\hline
\end{tabular}
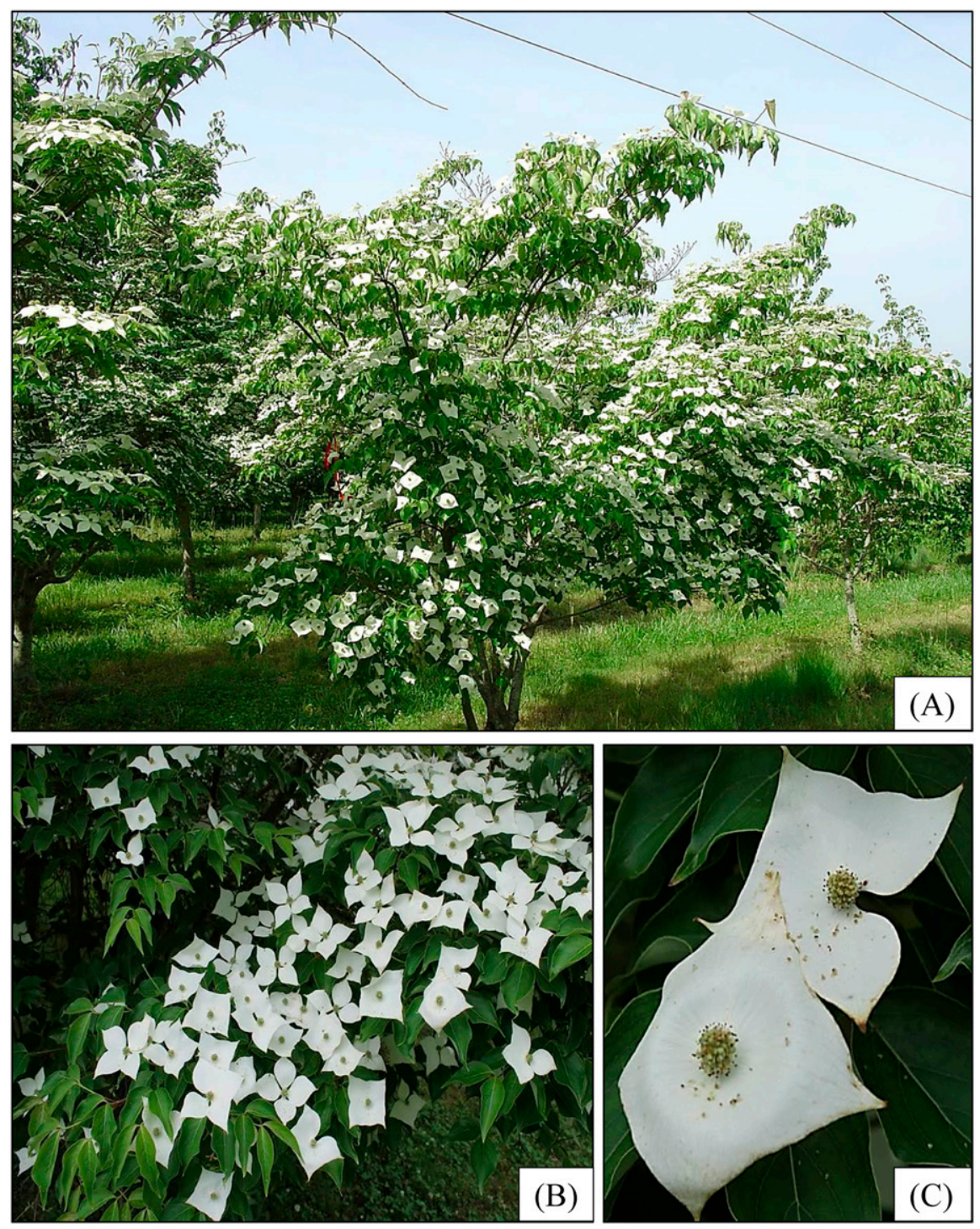

Fig. 2. Cornus kousa 'Pam's Mountain Bouquet' (A) original tree at 20 years old, (B-C) close-up of fused bract display.

described in Augé et al. (2002). Briefly, open-pollinated seeds were bulked from maternal parents 'Big Apple', 'Snowbird', 'Steeple', and an unnamed tree and the potential paternal parents 'Big Apple', 'Julian', 'Steeple', and an unnamed tree were provided by Polly Hill of Barnard's Inn Farm, MA, in 1989. In 1994, seedlings were placed in containers and evaluated for resistance to dogwood anthracnose (D. destructiva) and later planted in a field at the University of Tennessee Forest Resources AgResearch and Education Center in Oak Ridge, TN (USDA Hardiness Zone 7a) as described by Witte et al. (1996). These trees were also visually rated for powdery mildew resistance and those that were susceptible to the disease were removed.

\section{Description}

'Empire' is a brilliant, white-bracted kousa dogwood that has a columnar form (10.1 $\mathrm{m}$ tall by $1.2 \mathrm{~m}$ wide at 20 years) and exfoliating bark (Fig. 1). All references to color numbers for 'Empire' and subsequently described cultivars are from the Royal Horticultural Society (1982). The leaves are oppositely arranged and green (131C) that have the following characteristics: ovate-shaped; tip-acuminate; base-truncate; margin-entire; vestiture-puberulous, recticulate. The inflorescence is an umbel; bracts opposite, in two whorls with almost no overlap, not stiff; without petioles. The bract shape is ovate; base, truncate, tip-acuminate; margin-entire; vestiture-puberulous, reticulate. Outside mean bract length $3.2 \mathrm{~cm}(\mathrm{n}=10$; range, 2.9 to 3.5 $\mathrm{cm}$ ); outside bract mean width (widest point) $3.1 \mathrm{~cm}(\mathrm{n}=10$; range, 2.8 to $3.4 \mathrm{~cm})$; inside bract mean length $3.2 \mathrm{~cm}(\mathrm{n}=10$; range, 3.1 to $3.5 \mathrm{~cm}$ ); inside bract mean width (widest point) $3.1 \mathrm{~cm}(\mathrm{n}=10$; range, 2.8 to $3.4 \mathrm{~cm})$; peduncle stiff mean length $3.7 \mathrm{~cm}(\mathrm{n}=10$; range, 3.3 to $4.4 \mathrm{~cm})$; mean number of flowers per inflorescence $25(\mathrm{n}=10$; range, 22 to 30 ). Anthers are grayed yellow (161B) and the petals are yellow-green (145A), whereas the peduncle and peduncle base are yellow-green (144A). The exfoliated bark is grayed brown (199D) and the new bark is grayed green (189B). Dogwood anthracnose and powdery mildew were not observed on this tree.

'Pam's Mountain Bouquet' (patent pending) is a kousa dogwood with a spreading form that features a prolific fused bract display (Table 1; Fig. 2). The oppositely arranged leaves are green (143B) and are shaped ovate; tip-acuminate; base-truncate; margin-entire; vestiture-puberulous, recitculate. The inflorescence is an umbel; $83 \%$ of bracts are fused (Table 1), not stiff without petioles. The bract shape is ovate; base, truncate, tip-acuminate; margin-entire; vestiture-puberulous, reticulate. Inflorescence diagonal mean length $7.4 \mathrm{~cm}(\mathrm{n}=10$; range, 6.5 to $8.0 \mathrm{~cm}$ ); inflorescence mean length $5.4 \mathrm{~cm}(\mathrm{n}=10$; range, 4.4 to $6.2 \mathrm{~cm})$; inflorescence mean width $5.3 \mathrm{~cm}(\mathrm{n}=10$; range, 4.7 to $5.9 \mathrm{~cm}$ ); peduncle mean length $6.8 \mathrm{~cm}(\mathrm{n}=10$; range, 5.5 to $8.2 \mathrm{~cm})$; mean number of flowers per inflorescence 34 $(\mathrm{n}=10$; range, 27 to 41$)$. The anthers are grayed purple (N186B) and the petals are yellow-green $(145 \mathrm{C})$, whereas the peduncle and peduncle base are yellow-green (144B). The bark is grayed green (198B). Dogwood anthracnose and powdery mildew were not observed on this tree.

'Red Steeple' is a kousa dogwood that features a columnar-shaped canopy with red foliage that fades to green with high temperature and white bracts that have a red tin along the margins (Fig. 3). The oppositely arranged leaves are grayed red (178A) and are shaped ovate; tip-acuminate; base-truncate; margin-entire; vestiture-puberulous, recitculate. The inflorescence is an umbel; bracts opposite, in two whorls-inside bracts slightly overlap (30\% at widest point) outside bracts, without petioles, shape-ovate; base, truncate, tip-acuminate; margin-entire; vestiturepuberulous, reticulate. Outside bract mean length $3.4 \mathrm{~cm}(\mathrm{n}=10$; range, 3.2 to $3.6 \mathrm{~cm})$; outside bract mean width $2.0 \mathrm{~cm}(\mathrm{n}=10$; range, 1.7 to $2.4 \mathrm{~cm}$ ); inside bract mean length $3.3 \mathrm{~cm}(\mathrm{n}=10$; range, 3.1 to $3.5 \mathrm{~cm})$, inside bract mean width $1.9 \mathrm{~cm}(\mathrm{n}=10$; range, 1.7 to $2.2 \mathrm{~cm}$ ); peduncle stiff mean length $4.5 \mathrm{~cm}$ $(\mathrm{n}=10$; range, 3.6 to $5.0 \mathrm{~cm})$; mean number of 

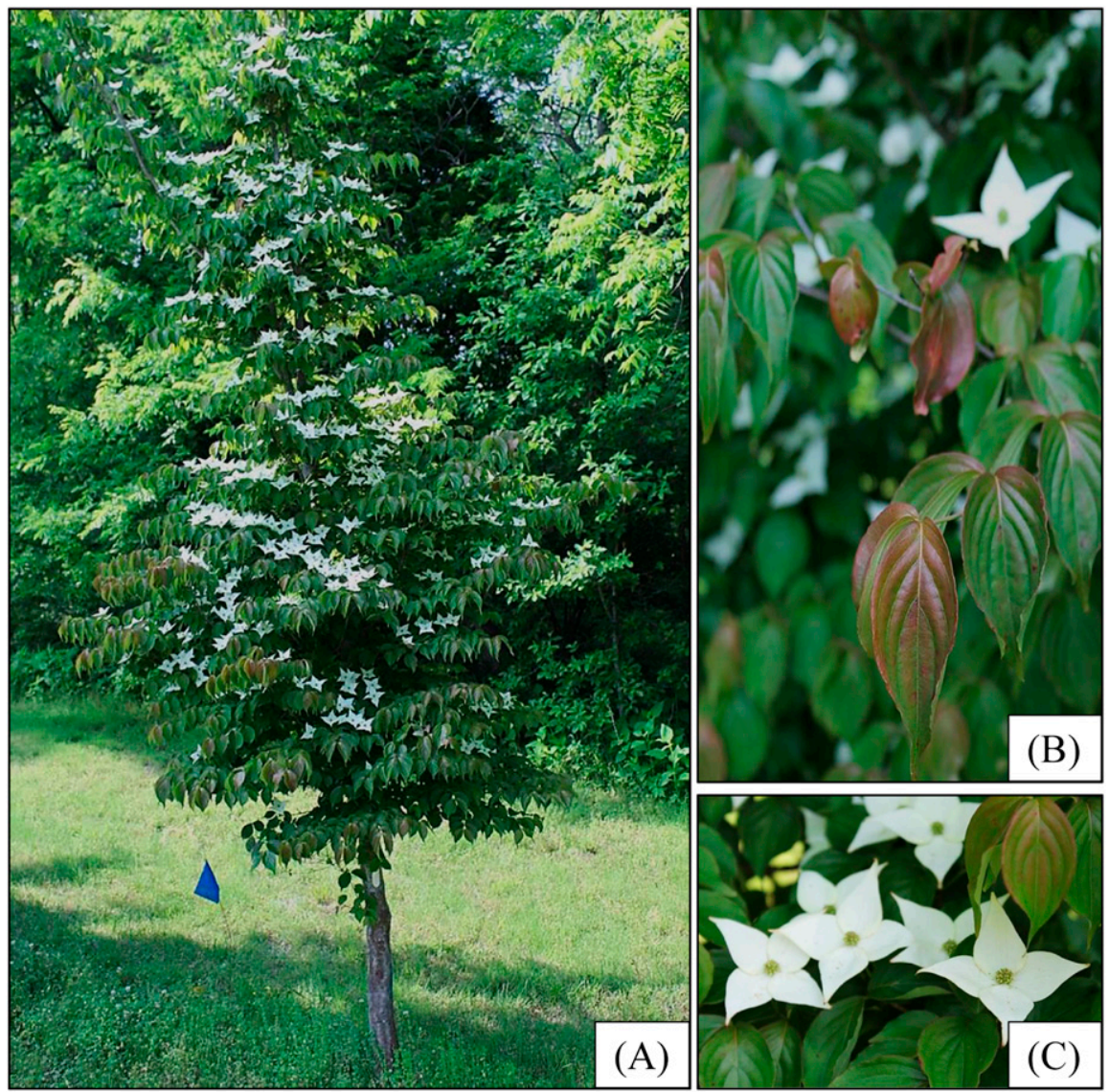

Fig. 3. Cornus kousa 'Red Steeple' (A) original tree at 20 years old, (B) red foliage that fades with high temperatures, $(\mathbf{C})$ bract display.

flowers per inflorescence $26(\mathrm{n}=10$; range, 22 to 30 ). The anthers are grayed yellow (162B) and the petals are yellow-green (145A), whereas the peduncle and peduncle base are yellow-green (144B) with some red-purple (60C) stippling in the base. Bracts are green-white $(157 \mathrm{~A})$ that have grayed red margins (180C). The bark is grayed green (198B). Dogwood anthracnose and powdery mildew were not observed on this tree.

\section{Molecular Identification of Cultivars Using Microsatellite Markers}

Microsatellite markers were used to compare 'Empire', 'Pam's Mountain Bouquet', and 'Red Steeple' to 26 cultivars and unnamed accessions of $C$. kousa that are maintained in the University of Tennessee's kousa dogwood collection. The methodology for isolation, polymerase chain reaction, and electrophoresis of DNA were as reported in Wadl et al. (2008a, 2008b). Data from the microsatellite loci were analyzed with POPULATIONS Version 1.2.32 (Langella, 2002) to estimate the shared allele distance (Jin and Chakraborty, 1994) and to create a pairwise matrix of genetic similarities. A dendrogram was generated from the similarity matrix by the unweighted pair group method using arithmetic averages (UPGMA).
The multilocus allelic data were used to create the allele-sharing distance matrix for the $C$. kousa genotypes and then a UPGMA tree was generated (Fig. 4). The pairwise similarity coefficients ranged from 0.40 to 1.00 and 155 of 406 pairwise comparisons were 0.75 or higher. The lower the value the more similar, the individual is based on the microsatellite analysis. All C. kousa individuals were separated and clustered into four main groups. 'Empire', 'Pam's Mountain Bouquet', and 'Red Steeple' are genetically distinct from the other 26 cultivars and lines. 'Empire' and 'Red Steeple' clustered with other upright or vase-shaped cultivars [Doubloon, National, and Steeple (Cappiello and Shadow, 2005)]. The high diversity indicated by the shared allele distances reflects the obligate outcrossing nature of dogwoods.

\section{Availability}

A plant patent has been applied for 'Pam's Mountain Bouquet'. A limited quantity of bud wood has been distributed to selected wholesale nurseries in Tennessee and Japan. Additional bulking of these cultivars through budding by selected nurseries (under confidentiality agreements and propagation agreements) has been accomplished. Contact R.N. Trigiano (rtrigian@utk.edu) for additional details.

\section{Literature Cited}

Augé, R.M., M.T. Windham, J.L. Moore, W.T Witte, E. Kubikova, W.E. Klingeman, R.M Evans, J.H. Reiss, P.C. Flanagan, and A.M. Saxton. 2002. Leaf curl water relations of kousa dogwoods showing resistance to summer stress. J. Environ. Hort. 20:143-147.

Cappiello, P. and D. Shadow. 2005. Dogwoods. Timber Press, Portland, OR.

Holmes, F.W. and C.R. Hibben. 1989. Field evidence confirms Cornus kousa dogwod's resistance to anthracnose. J. Arboric. 15:290291.

Jin, L. and R. Chakraborty. 1994. Estimation of genetic distance and coefficient of gene diversity from single-probe multilocus DNA fingerprinting data. Mol. Biol. Evol. 11:120127.

Langella, O. 2002. Populations: Population genetic software individuals or populations distances, phylogentie trees. 28 Mar. 2014. $<\mathrm{http}$ // www.hioinformatics.org/project/?group_id= $84>$.

Li, Y., M.T. Mmbaga, A.S. Windham, M.T Windham, and R.N. Trigiano. 2009. Powdery mildew of dogwoods: Current status and future prospects. Plant Dis. 93:1084-1092.

Ranney, T.G., L.F. Grand, and J. Knighten. 1995. Susceptibility of cultivars and hybrids of kousa dogwood to dogwood anthracnose. J. Arboric. 21:11-16.

Redlin, S.C. 1991. Discula destructive sp. nov., cause of dogwood anthracnose. Mycologia 83:633-642

Royal Horticultural Society. 1982. Royal Horticultural Society colour chart. Royal Horticultural Society, London, UK.

Simmons, M. 2002. Disease free dogwood on the way-Researchers hang hopes on wild trees. Knoxville News Sentinel (Sect. A1 Apr. Ed.: Section B, p. 1).

U.S. Dept. of Agriculture-National Agricultural Statistics Service. 2010. Census of horticultural specialties. Washington, DC.

Wadl, P.A., X. Wang, A.N. Trigiano, J.A. Skinner, M.T. Windham, R.N. Trigiano, T.A. Rinehart, S.M. Reed, and V.R. Pantalone. 2008a. Molecular identification keys for cultivars and lines of Cornus florida and C. kousa based on simple sequence repeat loci. J. Amer. Soc. Hort. Sci. 133:783-793.

Wadl, P.A., X. Wang, B.E. Scheffler, T.A. Rinehart, and R.N. Trigiano. 2008b. Microsatellites from kousa dogwood (Cornus kousa). Mol. Ecol. Res. 8:780-782.

Windham, M.T., E.T. Graham, W.T. Witte, J.L. Knighten, and R.N. Trigiano. 1998. Cornus florida 'Appalachian Spring': A white flowering dogwood resistant to dogwood anthracnose. HortScience 33:1265-1267.

Windham, M.T., W.T. Witte, and R.N. Trigiano. 2003. Three white-bracted cultivars of Cornus florida that are resistant to powdery mildew. HortScience 38:1253-1255.

Witte, W., M. Windham, and S. Schlarbaum. 1996. Variation of dogwood anthracnose resistance in half-sib families of Cornus kousa. Proc. of the Southern Nursery Research Conference 41:194-196.

Xiang, Q.Y., D.T. Thomas, W. Zhang, S.R. Manchester, and Z. Murrell. 2006. Species level phylogeny of the genus Cornus (Cornaceae) based on molecular and morphological evidence-Implications for taxonomy and Tertiary intercontinental migration. Taxon 55:9-30. 


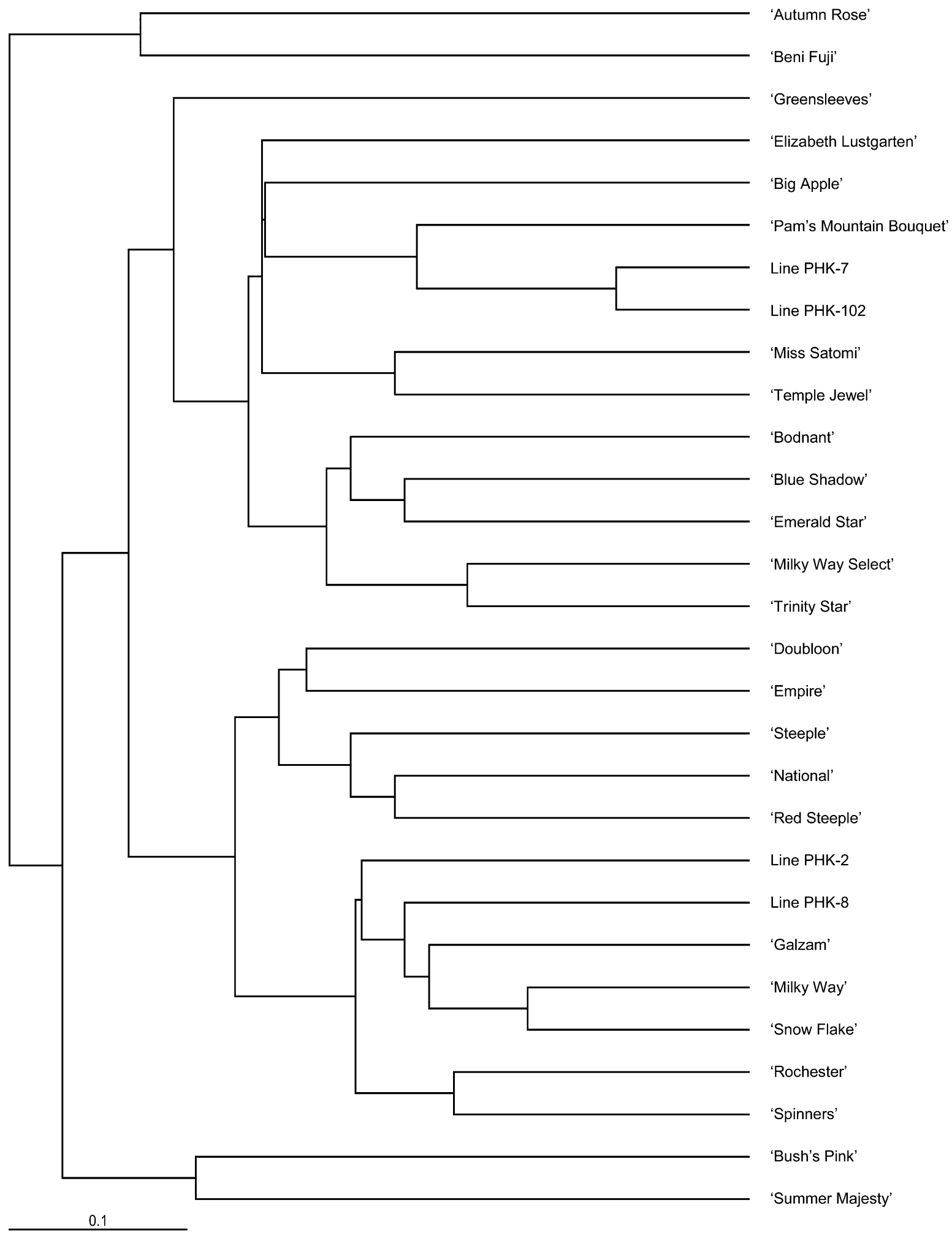

Fig. 4. Unweighted pair group method with arithmetic mean (UPGMA) cluster analysis of 29 cultivars and lines of Cornus kousa generated from the allele sharing distance matrix based on 11 microsatellite loci. 